\title{
Test Subject Supplier
}

National Cancer Institute

\section{Source}

National Cancer Institute. Test Subject Supplier. NCI Thesaurus. Code C90473.

The name of the organization that supplied the test subjects. 